University of Nebraska - Lincoln

DigitalCommons@University of Nebraska - Lincoln

Faculty Papers and Publications in Animal

Science

Animal Science Department

2005

\title{
An Evaluation of Production and Economic Efficiency of Two Beef Systems from Calving to Slaughter
}

\author{
R. V. Anderson \\ University of Nebraska-Lincoln \\ Richard J. Rasby \\ University of Nebraska-Lincoln, rrasby1@unl.edu \\ Terry J. Klopfenstein \\ University of Nebraska-Lincoln, tklopfenstein1@unl.edu \\ R. T. Clark \\ University of Nebraska-Lincoln
}

Follow this and additional works at: https://digitalcommons.unl.edu/animalscifacpub

Part of the Animal Sciences Commons

Anderson, R. V.; Rasby, Richard J.; Klopfenstein, Terry J.; and Clark, R. T., "An Evaluation of Production and Economic Efficiency of Two Beef Systems from Calving to Slaughter" (2005). Faculty Papers and Publications in Animal Science. 546.

https://digitalcommons.unl.edu/animalscifacpub/546

This Article is brought to you for free and open access by the Animal Science Department at DigitalCommons@University of Nebraska - Lincoln. It has been accepted for inclusion in Faculty Papers and Publications in Animal Science by an authorized administrator of DigitalCommons@University of Nebraska - Lincoln. 


\title{
An evaluation of production and economic efficiency of two beef systems from calving to slaughter ${ }^{1}$
}

\author{
R. V. Anderson*, R. J. Rasby*2, T. J. Klopfenstein*, and R. T. Clark $\dagger$ \\ *Department of Animal Science, University of Nebraska, Lincoln 68583-0908 and \\ $\dagger$ West Central Research and Extension Center, North Platte, NE 69101
}

\begin{abstract}
A 3-yr experiment was conducted with cows and their calves to evaluate resource inputs, animal performance, and carcass characteristics of two production systems. In the control system, cows (CON; $\mathrm{n}=99 / \mathrm{yr})$ grazed pasture and were fed hay during the winter, and CON steer calves were finished in the feedlot for $211 \mathrm{~d}$ after weaning. In the treatment system (TRT; $\mathrm{n}=100 / \mathrm{yr}$ ), cows grazed pasture and crop residue during the winter and were fed hay. Treatment steer calves grazed crop residue after weaning, grazed pasture in the spring and summer, and were finished in the feedlot for $90 \mathrm{~d}$. Body condition scores after TRT cows returned from crop residue grazing were greater $(P<0.01)$ for CON than for TRT cows. Calving rates were similar for both groups $(\mathrm{CON}=91 \%$; TRT $=93 \%)$. In the feedlot, CON steers had lower $(P<0.05)$ ADG and DMI, but were more efficient $(P<0.01)$ than TRT steers. Treatment steers had greater $(P<0.05)$ final weight, hot carcass weight and longissimus muscle area, and decreased marbling score. The cost per weaned calf and weaning breakeven were greater $(P=$ 0.07) for the CON system than for the TRT system
\end{abstract}

$(\mathrm{CON}=\$ 455.12, \$ 0.91 / 0.45 \mathrm{~kg} ; \mathrm{TRT}=\$ 421.43, \$ 0.84 /$ $0.45 \mathrm{~kg}$ ). When steers were priced into the postweaning phase on an economic basis, slaughter breakeven was lower $(P=0.01)$, and profit potential tended $(P=0.14)$ to be greater for TRT steers when they were sold on a live basis. When steers were priced into the postweaning phase on a financial basis, slaughter breakeven was lower $(P=0.03)$ and profit potential from the sale of steers on a live basis was greater $(P=0.07)$ for TRT than for CON steers. Economic evaluation of the total system resulted in greater $(P=0.06)$ profit potential for the TRT system when steers were priced into the system on either an economic or a financial basis and when steers were sold on a live basis, but no differences were observed when steers were sold on a grid basis. Despite differences in cow weight and body condition, calving rates did not differ between systems. Although calves were herdmates, feedlot performance and carcass characteristics differed between systems. The TRT system had lower weaning and slaughter breakeven, lower cost per weaned calf, and greater profit potential when finished steers were sold on a live basis.

\section{Key Words: Calf, Carcass, Cow, Economics, Performance, System}

(C2005 American Society of Animal Science. All rights reserved.

J. Anim. Sci. 2005. 83:694-704

\section{Introduction}

In many cow/calf systems, producers feed cows harvested forages after calving to avoid having cows in poor body condition. The costs associated with feeding harvested forages can make up more than half the total feed costs in maintaining a cowherd (Rasby et al., 1990). Grazing crop residues can decrease feed costs. Although additional costs associated with transporting cattle to crop residues for grazing may be incurred, it is often

\footnotetext{
${ }^{1}$ Published with the approval of the Director as Paper No. 14180, Journal Series, Nebraska Agric. Res. Div.

${ }^{2}$ Correspondence: C204 Animal Science Bldg. (phone: 402-4726477; fax: 402-472-6362; e-mail: rrasby1@unl.edu).

Received August 8, 2003.

Accepted December 8, 2004.
}

more economical than feeding harvested forages (Adams et al., 1996).

Most traditional beef finishing systems in the United States feed large amounts of grain and concentrate to weanlings for extended periods of time. Erickson (1997) estimated that 10 to 15 million cattle are in U.S. feedlots at one time, causing concern to the public regarding grain consumption and manure accumulation. In contrast, yearling beef systems employ extensive grazing of pasture and/or crop residues before a short finishing period before slaughter, and can produce carcasses with as desirable USDA yield and quality grades as those from calf-fed systems (Lunt and Orme, 1987). In addition, yearling systems from weaning to slaughter tend to result in lower breakeven prices and higher net profits (Sindt et al., 1991).

Although published literature addresses many individual aspects of beef production, insufficient research 
has been conducted to evaluate production systems from birth to slaughter and the economics of such systems. In addition, there are limited data comparing performance of calf-feds and yearling systems using herdmates. Therefore, the objectives of this experiment were to compare the performance and economics of cows and calves that are herdmates in a conventional beef production system with a system that matches cattle to the forage resource in a diversified farm setting.

\section{Materials and Methods}

\section{Production}

Cow/Calf. In yr 1 of this 3-yr experiment, 199 MARC II (1/4 Hereford, 1/4 Angus, 1/4 Simmental, 1/4 Gelbvieh), spring-calving (March and April) cows were stratified by age, BW, BCS, and expected calving date and assigned randomly into two treatment groups. Cows remained in their treatment groups throughout the experiment unless culled for reproductive failure.

The control (CON; $\mathrm{n}=99 / \mathrm{yr}$ ) treatment consisted of cows grazing dormant smooth bromegrass (Bromus inermis) pasture through the fall and winter and fed hay and protein supplement. The treatment (TRT; $\mathrm{n}=$ 100/yr) cows grazed cornstalks through the fall and winter and were only fed hay while grazing cornstalks if heavy snow and ice covered the field for 5 to $7 \mathrm{~d}$. The quantity of grain remaining in the field after harvest and before grazing occurred was recorded each year by determining the amount of grain on ears of corn per 0.443 ha as a measure of total diet quality.

All cows were supplemented with the same salt and mineral mix. Both groups were managed to achieve a mean BCS of 5 ( 1 = emaciated; 9 = obese; Richards et al., 1986) at calving. Each year, cows were managed as a single group from calving until cornstalks were available for TRT cows. Spring and summer pastures consisted of both cool- (smooth bromegrass, Bromus inermis) and warm- (big bluestem, Andropogon gerardii, indiangrass, Sorghastrum nutans, and switchgrass, Panicum virgatum) season grasses. Pastures before cornstalk grazing were vegetative (early fall) and dormant (late fall) smooth bromegrass. All cows were bred to Angus $\times$ Hereford bulls during a 65-d breeding season. Vaccination programs were the same for the two treatment groups.

Weights and BCS of all cows were determined at weaning in early to mid-October, immediately before TRT cows grazed cornstalk in November, and immediately after cornstalk grazing in January. Calving rates were determined at the end of calving based on whether a cow calved. Weaning rate was calculated by dividing the number of calves weaned by the number of cows exposed to bulls to produce that calf crop.

Replacement heifers were selected at weaning. Annually, $20 \%$ of the heifers from each treatment were retained as potential replacement females. Heifers retained as potential replacements were from a pool of heifers that were above average in actual weaning weight in each respective treatment group. The heaviest $2 \%$ of the heifers in each group were not retained as potential replacements. Retained heifers were fed a diet of $66 \%$ smooth bromegrass hay, $25 \%$ corn, and $9 \%$ protein supplement (DM basis) to gain $0.7 \mathrm{~kg} / \mathrm{d}$. Retained heifers were managed as a group until they entered their respective treatment groups as a pregnant first-calf heifer. Cows were removed from the experiment when they were not pregnant or did not wean a calf. Cull cows were replaced with a pregnant heifer from that treatment group in the fall of each year. The cost to develop a replacement heifer was recorded from weaning to the time she entered the cowherd at first calving.

Postweaning. Each year at weaning, steer calves from $\mathrm{CON}$ cows were transported to the University of Nebraska feedlot at the Agricultural Research and Development Center, where they were implanted with Synovex-S (Fort Dodge Animal Health, Overland Park, KS) and assigned randomly to one of two pens (22 steers per pen). A series of five step-up diets were fed following a 28 -d receiving period, beginning with a $50 \%$ concentrate diet and progressing to the $90 \%$ concentrate finishing diet (TDN 84\%, CP 12\%; DM basis) that was fed until slaughter. Calves were reimplanted with Revalor$\mathrm{S}$ (Intervet, Millsboro, DE) after $90 \mathrm{~d}$ on feed. Steers were slaughtered after being fed to a visually estimated $1 \mathrm{~cm}$ of 12 th-rib fat.

At weaning, steers from treatment cows were drylotted until cornstalks became available for grazing. After grazing cornstalks, TRT steers were again drylotted for the remainder of the wintering period until pasture was available for spring and summer grazing. The winter period included the days that TRT steers spent in both the drylot and grazing cornstalks. During the winter period, steers were supplemented with mineral and $2.3 \mathrm{~kg} \cdot$ steer $^{-1} \cdot \mathrm{d}^{-1}$ (DM basis) of wet corn gluten feed. Ammoniated wheat straw was fed during heavy snowcover and ad libitum in the drylot. Steers were implanted with Revalor-G (Intervet) before pasture grazing. Spring grazing pastures consisted of smooth bromegrass ( $B$. inermis), and summer grazing pastures consisted of big bluestem (A. gerardii), indiangrass $(S$. nutans), and switchgrass (P. virgatum). Following the summer grazing period, TRT steers entered the feedlot, were reimplanted (Revalor-S), and assigned randomly to one of two pens (22 steers per pen). Steers were then fed similarly to CON steers for the receiving and finishing periods. Twelfth-rib fat thickness was estimated in yr 1 and 2 every 2 wk near the end of the finishing period using ultrasound technology (Aloka 500, Corometrics Medical Systems, Wallingford, CT) and was estimated visually in yr 3. Treatment steers were slaughtered as a group when the estimated fat thickness was similar to CON steers.

All steers were weighed at weaning and at interim points throughout the postweaning phase. Steers were weighed following limit feeding ( $2 \%$ of $\mathrm{BW}, \mathrm{DM})$ of a 
$50 \%$ alfalfa hay and $50 \%$ wet corn gluten feed diet. Weights were taken before daily feeding on two consecutive days and averaged. Days on feed (DOF), pen DMI, ADG, and G:F were calculated. Average daily gain was calculated for TRT steers during the winter and summer periods. Carcass traits were recorded and included HCW, 12th-rib fat thickness (FAT), marbling score (MARB; $500=$ Small $^{00}$ or USDA quality grade Low Choice), yield grade (YG) determined by a USDA grader, and LM area (LMA). Estimated final weight was calculated by dividing HCW by $63 \%$. Because FAT at slaughter was different $(P<0.05)$ between CON $(1.62$ $\pm 0.05 \mathrm{~cm})$ and TRT $(1.39 \pm 0.05 \mathrm{~cm})$ steers, carcass data were adjusted to $28 \%$ empty body bat (EBF), or the amount of fat most closely correlated with the USDA quality grade of Low Choice, using the equation developed by Guiroy et al. (2001).

\section{Economics}

Cow/Calf. Cow cost, cost per weaned calf, and breakevens at weaning were calculated by evaluating annual inputs and revenues for each treatment group. The quantities of hay and supplements fed to cows and replacement heifers were recorded annually, as well as the number of days that each group of cows grazed pasture and/or cornstalks each year. Input costs did not account for management or overhead. Input costs did not account for all labor costs, such as when cows are managed together; however, most of the critical costs for labor are imbedded in pasture and cornstalk grazing costs, and in the feedlot phase, labor was included in yardage in both systems.

Grazing costs were based on 10-yr average rental rates for pasture in southeastern Nebraska (Johnson et al., 2001) of $\$ 20.68$ per 1.4 animal unit month (AUM). The grazing cost was assigned to a 540-kg cow and accounted for the forage consumed by her calf after 3 mo of age. Cost for grazing during the dormant season was assumed to be $75 \%$ of the value of grazing during the growing season. Grazing costs were subsequently adjusted for nonlactating, 540-kg mature cows (1.2 AUM); lactating, 440-kg first-calf heifers (1.0 AUM); pregnant, 400-kg long-yearling heifers (0.9 AUM); and pregnant, 360-kg yearling heifers (0.8 AUM) during either growing- or dormant-season grazing. Cornstalk grazing was priced at $\$ 0.25 \cdot \mathrm{cow}^{-1} \cdot \mathrm{d}^{-1}$ (Selley et al., 2001a).

Ten-year average prairie and alfalfa hay prices were $\$ 0.061 / \mathrm{kg}$ and $\$ 0.063 / \mathrm{kg}$, respectively (Selley et al., $2001 b$ ). Corn was priced at $\$ 0.092 / \mathrm{kg}$ (Selley et al., $2001 b)$. Protein, salt, and mineral were priced at $\$ 0.264 /$ kg (Selley et al., 2001a). Depreciation, interest on investment in equipment, and fuel costs associated with feeding were priced at $\$ 0.011 / \mathrm{kg}$ feed fed (R. T. Clark, Univ. of Nebraska, Lincoln, personal communication). Bull costs were based on ownership and feed costs, and estimated to be $\$ 20 /$ cow unit (Selley et al., 2001a).
Health costs per cow unit were $\$ 15$, which was similar to costs used in beef cow budgets (Selley et al., 2001a).

Initial cow costs were determined on a cow unit basis and included all costs described above, divided by the total number of cows and first-calf heifers expected to calve within each treatment group each year. Initial cow costs were adjusted for noncalf revenue by accounting for gains/losses on cull cows and heifers. Weaning rates did not differ $(P>0.10)$ between treatments, so cost per weaned calf was calculated by dividing the cow cost by the pooled weaning rate $(86.5 \%)$. Weaning rate from yr 1 was excluded from calculation because conception of calves for the first year of this experiment occurred before the onset of the experiment. Actual weaning weight did not differ $(P>0.10)$ between groups; therefore, breakeven at weaning was calculated by dividing cost per calf weaned by a pooled weaning weight (227 kg).

Gross cull cow sale value was calculated using $\$ 45.46 /$ $45 \mathrm{~kg}$ (Selley et al., 2001b), an assumed death loss of $1.5 \%$, and the average cull cow weight of $508 \mathrm{~kg}$ based on data from the experiment. Gross sale values were then adjusted for the base value of the cow, which was the summation of the cost per weaned calf, the cost per heifer associated with developing heifer calves to become first-calf heifers (beginning of first breeding season to weaning of first calf), and the cost per heifer associated with replacement heifer development (weaning to the beginning of first breeding season). This adjustment resulted in the cull cow basis value used to calculate gain/loss from the sale of cull cows.

Cull heifer gains/losses were calculated similarly, and included a price $/ 45 \mathrm{~kg}$ of $\$ 75$ (Feuz, 2001), a $1.5 \%$ death loss, and an average cull heifer weight of $431 \mathrm{~kg}$. The heifer base value used to adjust cull heifer sale value was the summation of the cost per weaned calf and the cost per head associated with replacement heifer development. The sum of the gain/loss on cull cows and heifers (noncalf revenue) was then divided by the total number of females expected to calve and added to the initial cow cost to determine adjusted cow cost.

Postweaning. Steers were priced into the postweaning phase of production using both the economic ( $\$ 85.76$ / $45 \mathrm{~kg}$; 15-yr average for the month in which the steer was weaned; Feuz et al., 2001) price of the weaned steer as well as financial (cost per weaned calf) cost of producing the steer. Trucking was priced at $\$ 0.011 / \mathrm{kg}$. Interest for operating capital was charged at an annual rate of $8.0 \%$. Interest was charged on the initial cost of all steers and on trucking for the entire postweaning ownership period. All feed inputs for each treatment group were recorded annually, as was the number of days the treatment steers were fed in a drylot, grazed cornstalks, and grazed pasture.

Postweaning death loss for steers was low and not different $(P>0.10)$ between CON ( 0 deaths) and TRT (two deaths; one death occurred while grazing cornstalks, and one death occurred in the finishing period). In addition, average number of steers treated annually 
was not different $(P>0.10)$ between treatments and averaged $12 \pm 7$ and $14 \pm 10$ steers yearly for the CON and TRT groups, respectively. Observed death losses in this experiment are lower than observed in the industry (Smith, 1998). In addition, as weight of the calf entering the feedlot increases, death loss decreases. Steers entering the feedlot that weighed less than $273 \mathrm{~kg}$ recorded a death loss of $2.4 \%$, whereas steers that weighed 364 $\mathrm{kg}$ when they entered the feedlot recorded a $0.61 \%$ death loss (Mark, 2001). For our economic analysis, we used $2 \%$ death loss postweaning for steers in the CON group and 1, 0.5, and $0.5 \%$ for the TRT group during the cornstalk grazing period, spring/summer grazing period, and finishing period, respectively (Jordon, 2000).

Control steers were charged $\$ 25 /$ steer for processing (implants, vaccinations, handling). Yardage was priced at $\$ 0.30^{-1} \cdot \mathrm{d}^{-1}$ steer. Finishing diets were priced at $\$ 0.139 / \mathrm{kg}$ (DM basis) (Jordon, 2000). Interest was charged on processing, yardage, and feed for half of the ownership period. A death loss of $2 \%$ was applied to the final live weight value of each steer.

All costs used in the TRT postweaning phase of analysis are based on the work of Jordon (2000). Treatment steers were charged a processing cost of $\$ 8.33 /$ steer for the wintering period, and interest was charged on processing for the entire ownership period. Drylot yardage before and after cornstalk grazing was priced at $\$ 0.23 \cdot$ steer $^{-1} \cdot \mathrm{d}^{-1}$. Cornstalk grazing was priced at $\$ 0.12 \cdot$ steer $^{-1} \cdot \mathrm{d}^{-1}$. The ammoniated wheat straw offered to steers during the winter period was $\$ 0.048$ per $\mathrm{kg}$ (as-fed) and intake was $5.59 \mathrm{~kg} \cdot \mathrm{steer}^{-1} \cdot \mathrm{d}^{-1}$ (as-fed). Wet corn gluten feed was priced to be equivalent to corn, and was $\$ 0.092 / \mathrm{kg}$ (DM basis) and fed at the rate of $2.27 \mathrm{~kg} \cdot$ steer $^{-1} \cdot \mathrm{d}^{-1}$ (DM basis). Mineral supplement (DM basis) for the TRT steers while in drylot was $\$ 0.373 / \mathrm{kg}$ and consumed at the rate of $0.07 \mathrm{~kg} \cdot \mathrm{steer}^{-}$ ${ }^{1} \cdot \mathrm{d}^{-1}$; cornstalk mineral supplement was consumed at the rate of $0.11 \mathrm{~kg} \cdot \mathrm{steer}^{-1} \cdot \mathrm{d}^{-1}$ and priced at $\$ 0.491 /$ $\mathrm{kg}$. Interest was charged on drylot yardage, cornstalk grazing, ammoniated wheat straw, wet corn gluten feed, and mineral for half of the wintering period and the rest of ownership. A $1 \%$ death loss was applied to the live weight value of the steer at the end of the wintering period.

During the summering period, TRT steers were charged $\$ 8.33 /$ steer for health and processing. Grazing costs were $\$ 0.45 \cdot$ steer $^{-1} \cdot \mathrm{d}^{-1}$, and interest was charged on both health and grazing costs for half the summering period and the rest of ownership. A $0.5 \%$ death loss was applied to the live weight value of the steer at the end of the summering period.

Costs for the TRT steer-finishing period were similar to those of CON steers, with the exception of processing being $\$ 8.33 /$ steer for TRT steers entering the feedlot. Interest was charged on processing, yardage, and feed for half the finishing period each year. A $0.5 \%$ death loss was applied to the final live weight value of the steer.
The live value was determined using treatment mean final weights for each year and the 15-yr average live weight price for fed steers in Nebraska for month of slaughter (Feuz et al., 2001). Breakevens were calculated by dividing the total costs of the postweaning phase of the system by the treatment mean final weight for each respective year. Profit/loss per steer (live basis) was determined using total costs and live weight value. The economics of the postweaning phase of the TRT system also were evaluated at the end of the wintering period, the end of the summering period, and at the end of the finishing period.

Profit/loss per steer was determined for each system using a value-based grid developed by MacDonald (2002). The basis used was the 1990 to 2000 average Nebraska-dressed, fed-cattle price each year for the appropriate month (Feuz et al., 2001). The 1990 to 2000 average USDA Quality Grade Choice/Select price spreads for the appropriate month (Feuz et al., 2001) were used to calculate premiums and discounts for marbling.

Systems. Control and treatment systems were compared each year on an economic and a financial basis. Costs and revenues were calculated on a per-cow-exposed basis by assuming a 100-cow herd, using the actual pooled weaning rate $(86.5 \%)$, and assuming a 50:50 ratio of steers and heifers at weaning. Net system revenue was determined from the difference between systems costs and revenues, and then divided by 100 to establish net revenue per cow exposed. Economically and financially based analyses used the summation of adjusted cow cost and the accrued costs of producing a steer for slaughter that included interest and excluded initial cost of purchasing the steer into the postweaning phase. Systems revenues accounted for the sale of weaned, nonreplacement heifers as well as the sale of finished steers. Net income/loss was then found for the difference between costs and revenues, and was calculated on both a live-weight market steer basis and on a grid basis (MacDonald, 2002).

\section{Statistics}

Cow production data were analyzed (Adams et al., 2000) using the Mixed procedures of SAS (SAS Inst., Inc., Cary, NC). In this procedure, individual cow was the experimental unit and the treatment $\times$ year interaction was tested because year was a fixed variable and not a random variable. Reproductive data were analyzed as a binomial distribution using the logit statement, and treatment-year class was the experimental unit. Steer performance and carcass data were analyzed using pen (two pens per year) as the experimental unit with year as a random variable. Economic data were analyzed using PROC GLM, where treatment-year class was the experimental unit.

\section{Results and Discussion}

\section{Production}

Cow/Calf. During the winter each year, number of days for the pasture grazing period averaged $58 \pm 4 \mathrm{~d}$ 
Table 1. Cow BW $(\mathrm{kg})$ and BCS for control (CON) and treatment (TRT) systems

\begin{tabular}{|c|c|c|c|}
\hline Item & $\mathrm{CON}$ & TRT & SE \\
\hline No. ${ }^{\mathrm{a}}$ & 99 & 100 & - \\
\hline Weight $1^{b}$ & 526 & 530 & 7 \\
\hline $\mathrm{BCS} 1^{\mathrm{b}}$ & 5.2 & 5.2 & 0.1 \\
\hline Weight $2^{c}$ & 531 & 536 & 7 \\
\hline $\mathrm{BCS} 2^{\mathrm{c}}$ & 5.2 & 5.2 & 0.1 \\
\hline Weight $3^{\mathrm{d}}$ & $578^{* *}$ & $549^{* * *}$ & 7 \\
\hline $\mathrm{BCS} 3^{\mathrm{d}}$ & $5.5^{* *}$ & $5.3^{* *}$ & 0.1 \\
\hline
\end{tabular}

${ }^{\mathrm{a} N u m b e r}$ of cows per year.

${ }^{\mathrm{b}} \mathrm{BW}$ and BCS ( 1 = emaciated; $9=$ obese $)$ at weaning.

${ }^{\mathrm{C}} \mathrm{BW}$ and BCS before cornstalk grazing.

${ }^{\mathrm{d}} \mathrm{BW}$ and BCS after cornstalk grazing.

**Numbers in the row differ, $P<0.01$.

for CON and $22 \pm 3 \mathrm{~d}$ for TRT cows. Treatment cows grazed cornstalks for an average of $91 \pm 10 \mathrm{~d}$ each year. Both groups grazed spring and summer pastures for $173 \pm 8 \mathrm{~d}$ on average each year.

Cow weight and BCS for the CON and TRT systems are summarized in Table 1 . There were no treatment $\times$ year interactions, so only treatment means are listed. Cow BW and BCS were similar at weaning and before cornstalk grazing. The BCS and BW after cornstalk grazing were greater $(P<0.01)$ for CON cows than for TRT cows. Differences in cow weight and BCS immediately after TRT cows were removed from cornstalks were due to variation in grazed forage quality and availability between treatment groups. The estimate of the amount of corn grain remaining in fields after harvest and before TRT cow grazing was $51 \mathrm{~kg} / \mathrm{ha}$ in yr 1 and $25 \mathrm{~kg} / \mathrm{ha}$ in yr 2 and 3 . Although not measured, dormant bromegrass pastures grazed by CON cows during the late fall and early winter, when TRT cows were grazing cornstalks, was abundant due to timely moisture during the late summer and early fall. These differences in total forage quality resulted in differences in BCS and $\mathrm{BW}$ of cows in the CON and TRT groups.

Despite differences in cow BW and BCS after cornstalk grazing, calving rates did not differ $(\mathrm{CON}=91 \pm$ $1.2 \%$; TRT $=93 \pm 1.1 \%$ ). This is in agreement with Morrison et al. (1999) and Freetly et al. (2000), who observed no differences in pregnancy rates of cows that experienced changes in body energy reserves during the last trimester of pregnancy when calving in moderate body condition. Conversely, Selk et al. (1988) reported that precalving BCS and changes in cow BW between 2 and 4 mo before parturition were major factors influencing pregnancy rate, and cows that calve in a BCS of less than 5 have compromised rebreeding performance. In the present study, all cows calved with a BCS at or near 5. In addition, weaning rate was similar between CON and TRT systems, and averaged 86.5 $\pm 1.5 \%$.

Postweaning performance of TRT steers varied by year due to the amount of grain left in the cornstalk fields and the quality and quantity of the forages for grazing in the spring and summer. Average BW for TRT steers entering the winter period was $227 \pm 4 \mathrm{~kg}$ and entering the spring/summer period was $332 \pm 5$ $\mathrm{kg}$. Days in each period and ADG for TRT steers after weaning and before entering the feedlot averaged 197 $\mathrm{d}, 0.53 \mathrm{~kg} / \mathrm{d}$ and $118 \mathrm{~d}, 0.93 \mathrm{~kg} / \mathrm{d}$ for the winter and spring/summer periods, respectively.

Feedlot performance data for CON and TRT steers are summarized in Table 2 . Steer BW immediately after weaning did not differ between treatments, and averaged $227 \pm 4 \mathrm{~kg}$. This was expected because both treatment groups were managed together from birth until weaning. During the finishing phase, CON steers averaged $211 \mathrm{DOF}$ and TRT steers averaged $90 \mathrm{DOF}$. When data were adjusted to a constant body composition of $28 \%$ EBF (Guiroy et al., 2001), DOF was $171 \mathrm{~d}$ for CON steers and $72 \mathrm{~d}$ for TRT steers. The steers from both treatments initially had more than $28 \% \mathrm{EBF}$, so adjusted DOF reflects the decrease in the time it would have taken for CON and TRT steers to reach $28 \% \mathrm{EBF}$.

Control steers had lower $(P<0.05)$ ADG compared with TRT steers (Table 2). In addition, DMI was greater $(P<0.01)$ and G:F was lower $(P<0.01)$ for TRT steers. Sindt et al. (1991) compared performance of calf-feds and yearlings of similar genetic background and reported higher $\mathrm{ADG}$ and feed intake and lower efficiency in the feedlot for yearlings than for calf-feds. Final BW, as estimated using hot carcass weight, was greater $(P$

Table 2. Feedlot performance of steers from control (CON) and treatment (TRT) systems with year as a random variable

\begin{tabular}{lccccc}
\hline \hline Item & CON & Adjusted $^{\mathrm{a}}$ & TRT & Adjusted $^{\mathrm{a}}$ & SE \\
\hline No. of steers & 127 & - & 132 & - & - \\
Days on feed & $211^{* *}$ & 171 & $90^{* *}$ & 72 & 5 \\
Initial BW, kg & $225^{* *}$ & - & $443^{* *}$ & - & 4 \\
ADG, kg/d & $1.50^{*}$ & - & $1.95^{*}$ & - & 0.07 \\
Final BW, kg & $541^{*}$ & 481 & $13.9^{* *}$ & 583 & 15 \\
DMI & $8.6^{* *}$ & - & $0.14^{* *}$ & - & 0.4 \\
G:F & $0.18^{* *}$ & - & & - & 0.07 \\
\hline
\end{tabular}

a Data adjusted to $28 \%$ empty body fat (Guiroy et al., 2001).

${ }^{\mathrm{b}}$ Estimated from hot carcass weight adjusted to a $63 \%$ dress.

*Numbers within a row differ, $P<0.05$.

**Numbers within a row differ, $P<0.01$. 
Table 3. Adjusted and actual carcass data of steers in the control (CON) and treatment (TRT) systems using year as a random variable

\begin{tabular}{|c|c|c|c|c|c|c|}
\hline \multirow[b]{2}{*}{ Item } & \multicolumn{2}{|c|}{ Adjusted $^{\mathrm{a}}$} & \multirow[b]{2}{*}{$\mathrm{SE}$} & \multicolumn{2}{|c|}{ Actual } & \multirow[b]{2}{*}{$\mathrm{SE}$} \\
\hline & $\mathrm{CON}$ & TRT & & $\mathrm{CON}$ & TRT & \\
\hline No. of steers & 127 & 132 & - & 127 & 132 & - \\
\hline $\mathrm{HCW}, \mathrm{kg}$ & $303^{*}$ & $367^{*}$ & 10 & $341^{*}$ & $390^{*}$ & 10 \\
\hline $\mathrm{LM}$ area, $\mathrm{cm}^{2}$ & $69.53^{*}$ & $81.79 *$ & 1.55 & $74.76^{*}$ & $84.17^{*}$ & 1.48 \\
\hline 12th-rib fat thickness, $\mathrm{cm}$ & 1.37 & 1.28 & 0.04 & $1.62^{*}$ & $1.39 *$ & 0.05 \\
\hline Yield grade & 2.8 & 2.8 & 0.1 & $3.2^{*}$ & $2.9^{*}$ & 0.1 \\
\hline Marbling score ${ }^{\mathrm{b}}$ & $530^{*}$ & $467^{*}$ & 16 & $588^{*}$ & $493^{*}$ & 16 \\
\hline
\end{tabular}

*Numbers in a row within either the Adjusted or Actual column differ, $P<0.05$.

aData adjusted to $28 \%$ empty body fat (Guiroy et al., 2001).

${ }^{\mathrm{b}}$ Marbling score: $500=$ Small $^{00}$ (USDA quality grade of Low Choice).

$<0.05)$ for TRT than for CON steers. Sindt et al. (1991) reported a 40-kg difference between final weights in favor of yearlings compared with calf-feds at slaughter. Jordon (2000) observed yearling final weights over 600 $\mathrm{kg}$, which is in accord with the results of the present study.

Carcass data for CON and TRT steers adjusted to $28 \%$ EBF are summarized in Table 3. Control steers had lighter $(P<0.05) \mathrm{HCW}$ compared with TRT steers. As reflected by decreased carcass weight, LMA were smaller $(P<0.05)$ for CON than TRT steers. These results agree with those of Hickok et al. (1992), who observed heavier carcass weights and larger LM areas in steers fed as yearlings compared with steers fed as calf-feds. Yearlings produce heavier carcasses and more muscle because they have been developed further along their growth curve (Stock et al., 1990). This increase in bone and muscle tissue growth before fattening that occurs in steers grown in a more forage-extensive system is most readily observed when compared with calffeds at the same dressing percent.

Twelfth-rib fat thickness and yield grade did not differ between treatment groups after adjustment to $28 \%$ EBF (Table 3). Control steers had higher $(P<0.05)$ marbling scores than TRT steers. The improvement in marbling score observed in CON steers was a result of time on feed (Hancock et al., 1987; Van Koevering et al., 1995; Klopfenstein et al., 2000). The higher mar- bling score for the CON steers also implies that a higher percentage of steers would grade USDA quality grade Low Choice or greater compared with TRT steers. Sindt et al. (1991) observed an increase in the number of USDA Choice carcasses in calf-feds after nearly twice as many days on feed compared with yearlings. Conversely, Gill et al. (1993) and Hickok et al. (1992) did not observe any differences between calf-feds and yearlings with regard to marbling scores and percentage of USDA Choice carcasses.

\section{Economics}

Cow/Calf. A summary of the economic evaluation of the CON and TRT systems before weaning is reported in Table 4. Cost per weaned calf $(\$ 455.12, \mathrm{CON}$; $\$ 421.43$, TRT) and weaning breakeven $(\$ 0.91 / 0.45 \mathrm{~kg}$, CON; $\$ 0.84 / 0.45 \mathrm{~kg}$, TRT) were higher $(P=0.07)$ for CON cows than for TRT cows. These differences are due to differences in input costs, particularly in hay expense. Annually, the cow and her share of replacement heifers and heifer calves consumed hay at a rate of 1,426 and $933 \mathrm{~kg} / \mathrm{cow}$ unit for the CON and TRT systems, respectively. This resulted in all annual costs associated with harvested forages feeding being $\$ 120.83$ per cow unit for CON cows and $\$ 90.69$ per cow unit for TRT cows.

The differences in hay costs and subsequent differences in cost per weaned calf and weaning breakeven

Table 4. Yearly cow cost per cow, cost per calf weaned, and breakeven excluding management, labor and overhead for control (CON) and treatment (TRT) systems

\begin{tabular}{|c|c|c|c|c|}
\hline Item & $\mathrm{CON}$ & TRT & $P$-value & $\mathrm{SE}$ \\
\hline No. $^{a}$ & 99 & 100 & - & - \\
\hline Initial cow cost, $\$$ & 339.75 & 316.46 & - & - \\
\hline Noncalf revenue, $\$^{\mathrm{b}}$ & $(53.93)$ & $(48.08)$ & - & - \\
\hline Adjusted cow cost, $\$^{\mathrm{c}}$ & 393.68 & 364.54 & - & - \\
\hline Cost/weaned calf, $\$^{\mathrm{d}}$ & 455.12 & 421.43 & 0.07 & 6.83 \\
\hline Breakeven, $\$ / 0.45 \mathrm{~kg}^{\mathrm{e}}$ & 0.91 & 0.84 & 0.07 & 0.01 \\
\hline
\end{tabular}


Table 5. Postweaning cost, breakeven, revenue, and net profit/loss per steer for the control $(\mathrm{CON})$ and treatment (TRT) systems when steers are priced into the postweaning phase of production on an economic (opportunity cost) basis excludng management, labor, and overhead

\begin{tabular}{|c|c|c|c|c|}
\hline Item & $\mathrm{CON}$ & TRT & $P$-value & $\mathrm{SE}$ \\
\hline \multicolumn{5}{|l|}{ Winter period $^{\mathrm{a}}$} \\
\hline Initial steer cost, $\$ /$ steer $^{\mathrm{b}}$ & 433.95 & 433.95 & - & - \\
\hline Trucking, $\$ /$ steer & 2.53 & 2.53 & - & - \\
\hline Processing, $\$ /$ steer & - & 8.33 & - & - \\
\hline Drylot yardage, $\$ /$ steer & - & 27.60 & - & - \\
\hline Cornstalks, $\$ /$ steer & - & 9.28 & - & - \\
\hline Wet corn gluten feed, $\$ /$ steer & - & 55.79 & - & - \\
\hline Mineral, \$/steer & - & 5.04 & - & - \\
\hline Wheat straw, $\$ /$ steer & - & 32.55 & - & - \\
\hline Death loss, $\$ /$ steer & - & 5.79 & - & - \\
\hline Interest, $\$ /$ steer $^{\mathrm{c}}$ & - & 27.93 & - & - \\
\hline Total cost, $\$ /$ steer & - & 608.79 & - & - \\
\hline $\mathrm{BW}, \mathrm{kg}$ & - & 332 & - & - \\
\hline Breakeven, $\$ / 0.45 \mathrm{~kg}$ & - & 0.83 & - & - \\
\hline Revenue, $\$ /$ steer & - & 578.61 & - & - \\
\hline Net profit/loss, $\$ /$ steer & - & $(30.18)$ & - & - \\
\hline \multicolumn{5}{|l|}{ Summer period ${ }^{\mathrm{a}}$} \\
\hline Initial steer cost, $\$ /$ steer $^{b}$ & - & 578.61 & - & - \\
\hline Grazing, $\$ /$ steer & - & 52.95 & - & - \\
\hline Processing, $\$ /$ steer & - & 8.33 & - & - \\
\hline Death loss, $\$ /$ steer & - & 3.53 & - & - \\
\hline Interest, $\$ /$ steer $^{\mathrm{c}}$ & - & 13.37 & - & - \\
\hline Total cost, $\$ /$ steer & - & 656.80 & - & - \\
\hline $\mathrm{BW}, \mathrm{kg}$ & - & 433 & - & - \\
\hline Breakeven, $\$ / 0.45 \mathrm{~kg}$ & - & 0.67 & - & - \\
\hline Revenue, $\$ /$ steer & - & 706.86 & - & - \\
\hline Net profit/loss, $\$ /$ steer & - & 50.07 & - & - \\
\hline \multicolumn{5}{|l|}{ Finishing period ${ }^{\mathrm{a}}$} \\
\hline Initial steer cost, $\$ /$ steer $^{\mathrm{b}}$ & - & 706.86 & - & - \\
\hline Feed, \$/steer & 251.07 & 174.26 & - & - \\
\hline Yardage, \$/steer & 63.20 & 27.00 & - & - \\
\hline Processing, $\$ /$ steer & 25.00 & 8.33 & - & - \\
\hline Death loss, $\$ /$ steer & 14.95 & 4.46 & - & - \\
\hline Interest, $\$ /$ steer $^{\mathrm{c}}$ & 27.21 & 11.08 & - & - \\
\hline Total steer cost, $\$ /$ steer & 817.91 & 932.00 & - & - \\
\hline Final BW, kg & 481 & 583 & - & - \\
\hline Breakeven, $\$ / 0.45 \mathrm{~kg}$ & 0.77 & 0.72 & 0.01 & 0.01 \\
\hline Revenue, live basis, $\$ /$ steer $^{\mathrm{d}}$ & 747.55 & 892.23 & - & - \\
\hline Net profit/loss, live basis, $\$ /$ steer & $(70.36)$ & $(39.77)$ & 0.14 & 9.17 \\
\hline Revenue, grid basis, $\$ /$ steer $^{\mathrm{e}}$ & 770.75 & 885.14 & - & - \\
\hline Net profit/loss, grid basis, $\$ /$ steer & $(47.16)$ & $(46.86)$ & 0.99 & 20.34 \\
\hline
\end{tabular}

${ }^{a}$ Winter period = weaning to spring grazing; Summer period = grazing cool- and warm-season pastures; Finishing period $=$ drylot finishing until slaughter.

${ }^{b}$ Economic steer cost $=$ cost of steer if it had been purchased using the 15 -yr average price for steers for the appropriate month and weight (Feuz et al., 2001b). c8.0 annual percentage rate.

${ }^{d}$ Revenue generated from the sale of a steer using weight and price categories for the month in which the steer was sold at the end of the finishing period.

${ }^{e}$ Revenue generated from the sale of a steer using a pricing grid (MacDonald, 2002).

between treatment groups illustrate the effect that harvested forage feeding costs have on cost per unit of production. Rasby et al. (1990) also observed diversity in costs between producers that participated in an Integrated Resource Management program in Nebraska. Over $2 \mathrm{yr}$, the range in cost to produce a weaned calf was $\$ 327$ to $\$ 501$, and harvested forage cost ranged from only $\$ 7$ to $\$ 126$. It was further noted that the producers with a lower investment in harvested forage feeding also had lower overall feed costs and were able to produce weaned calves with less expenses.

Postweaning Economic Analysis. Postweaning steer costs and revenues for the control and treatment groups when steers are purchased into the system on an economic basis are presented in Table 5. Slaughter breakevens were different $(P=0.01)$ between groups. Net profit/loss derived from live animal sale tended to be less $(P=0.14)$ for the CON system; in the finishing 
Table 6. Postweaning cost, breakeven, revenue, and net profit/loss per steer for the control $(\mathrm{CON})$ and treatment (TRT) systems when steers are priced into the postweaning phase of production on a financial (cost of production) basis excluding management, labor, and overhead

\begin{tabular}{|c|c|c|c|c|}
\hline Item & $\mathrm{CON}$ & TRT & $P$-value & $\mathrm{SE}$ \\
\hline \multicolumn{5}{|l|}{ Winter period $^{\mathrm{a}}$} \\
\hline Initial steer cost, $\$ /$ steer $^{b}$ & 455.12 & 421.43 & - & - \\
\hline Trucking, $\$ /$ steer & 2.53 & 2.53 & - & - \\
\hline Processing, $\$ /$ steer & - & 8.33 & - & - \\
\hline Drylot yardage, $\$ /$ steer & - & 27.60 & - & - \\
\hline Cornstalks, $\$ /$ steer & - & 9.28 & - & - \\
\hline Wet corn gluten feed, $\$ /$ steer & - & 55.79 & - & - \\
\hline Mineral, $\$ /$ steer & - & 5.04 & - & - \\
\hline Wheat straw, $\$ /$ steer & - & 32.55 & - & - \\
\hline Death loss, $\$ /$ steer & - & 5.79 & - & - \\
\hline Interest, $\$ /$ steer $^{\mathrm{c}}$ & - & 27.12 & - & - \\
\hline Total cost, $\$ /$ steer & - & 595.46 & - & - \\
\hline $\mathrm{BW}, \mathrm{kg}$ & - & 332 & - & - \\
\hline Breakeven, $\$ / 0.45 \mathrm{~kg}$ & - & 0.81 & - & - \\
\hline Revenue, $\$ /$ steer & - & 578.61 & - & - \\
\hline Net profit/loss, $\$ /$ steer & - & $(16.85)$ & - & - \\
\hline \multicolumn{5}{|l|}{ Summer period $^{\mathrm{a}}$} \\
\hline Initial steer cost, $\$ /$ steer $^{\mathrm{b}}$ & - & 595.46 & - & - \\
\hline Grazing, $\$ /$ steer & - & 52.95 & - & - \\
\hline Processing, $\$ /$ steer & - & 8.33 & - & - \\
\hline Death loss, $\$ /$ steer & - & 3.53 & - & - \\
\hline Interest, $\$ /$ steer $^{\mathrm{c}}$ & - & 12.74 & - & - \\
\hline Total steer cost, $\$ /$ steer & - & 673.02 & - & - \\
\hline $\mathrm{BW}, \mathrm{kg}$ & - & 433 & - & - \\
\hline Breakeven, $\$ / 0.45 \mathrm{~kg}$ & - & 0.69 & - & - \\
\hline Revenue, $\$ /$ steer & - & 706.86 & - & - \\
\hline Net profit/loss, $\$ /$ steer & - & 33.84 & - & - \\
\hline \multicolumn{5}{|l|}{ Finishing period $^{\mathrm{a}}$} \\
\hline Initial steer cost, $\$ /$ steer $^{\mathrm{b}}$ & - & 673.02 & - & - \\
\hline Feed, $\$ /$ steer & 251.07 & 174.26 & - & - \\
\hline Yardage, $\$ /$ steer & 63.20 & 27.00 & - & - \\
\hline Processing, $\$ /$ steer & 25.00 & 8.33 & - & - \\
\hline Death loss,$/ \$ /$ steer & 14.95 & 4.46 & - & - \\
\hline Interest, $\$ /$ steer $^{\mathrm{c}}$ & 28.20 & 10.74 & - & - \\
\hline Total cost, $\$ /$ steer & 840.07 & 897.81 & - & - \\
\hline Final BW, kg & 481 & 583 & - & - \\
\hline Breakeven, $\$ / 0.45 \mathrm{~kg}$ & 0.79 & 0.70 & 0.03 & 0.01 \\
\hline Revenue, live basis, $\$ /$ steer $^{\mathrm{d}}$ & 747.55 & 892.23 & - & - \\
\hline Net profit/loss, live basis, $\$ /$ steer & $(92.52)$ & $(5.58)$ & 0.07 & 17.23 \\
\hline Revenue, grid basis, $\$ /$ steer $^{\mathrm{e}}$ & 770.75 & 885.14 & - & - \\
\hline Net profit/loss, grid basis, $\$ /$ steer & $(69.32)$ & (12.67) & 0.28 & 27.72 \\
\hline
\end{tabular}

${ }^{\text {a}}$ Winter period $=$ weaning to spring grazing; Summer period = grazing cool- and warm-season pastures; Finishing period $=$ drylot finishing until slaughter.

${ }^{\mathrm{b}}$ Financial steer cost $=$ cost to produce a steer to that period.

c8.0 annual percentage rate.

${ }^{\mathrm{d}}$ Revenue generated from the sale of a steer using weight and price categories for the month in which the steer was sold at the end of the finishing period.

${ }^{\text {e}}$ Revenue generated from the sale of a steer using a pricing grid (MacDonald, 2002).

period, the CON system lost $\$ 30.59$ more per steer than the TRT system. When steers were sold using the grid, profit/loss was not different. Final BW for TRT steers averaged $619 \pm 15 \mathrm{~kg}$, compared with $541 \pm 15 \mathrm{~kg}$ for CON steers. Calculating breakevens and net profit/loss based on live weight reflect the difference in final BW, which agrees with the results of Shain et al. (1998), who found that slaughter breakeven was negatively correlated with final finishing BW in each year of a 5-yr study. Similar results were reported by Jordon (2000).
Finally, because TRT steers were heavier at the end of the feedlot period, they had lower breakevens and improved profit potential when sold on a live basis compared with CON steers. However, when steers were sold on a grid basis, breakevens did not differ because fewer TRT steers graded USDA Low Choice or better. MacDonald (2002) noted that considerable variation exists in weight and fat thickness of yearling cattle slaughtered at one time. The author further hypothesized that sorting strategies in yearling production sys- 
Table 7. Net revenue or loss generated for control (CON) and treatment (TRT) systems when steers are priced into the postweaning phase of production on an economic (opportunity cost) basis, excluding managemeng, labor, and overhead ${ }^{a}$

\begin{tabular}{lcccc}
\hline \hline Item & CON & TRT & $P$-value & SE \\
\hline${\text { Cow cost, } \$^{\mathrm{b}}}_{\text {Steer cost (economic), } \$^{\mathrm{c}}}$ & $39,367.67$ & $36,454.00$ & - & - \\
Total system cost, $\$$ & $16,510.20$ & $21,416.15$ & - & - \\
Steer revenue (live basis), $\$^{\mathrm{d}}$ & $55,877.95$ & $57,870.15$ & - & - \\
Heifer revenue, $\$^{\mathrm{e}}$ & $32,145.65$ & $38,365.89$ & - & - \\
System revenue (live basis), $\$$ & $17,790.39$ & $17,790.39$ & - & - \\
Net revenue/cow exposed (live basis), $\$$ & $49,936.04$ & $56,156.28$ & - & - \\
Steer revenue (grid basis), $\$^{\mathrm{f}}$ & $(59.42)$ & $(17.14)$ & 0.08 & - \\
Heifer revenue, $\$^{\mathrm{e}}$ & $33,142.25$ & $38,061.16$ & - & - \\
System revenue (grid basis), $\$$ & $17,790.39$ & $17,790.39$ & - & - \\
Net revenue/cow exposed (grid basis), $\$$ & $50,932.64$ & $55,851.55$ & - & 14.45 \\
\hline
\end{tabular}

${ }^{\mathrm{a}}$ Economic steer cost $=$ cost of steer if it had been purchased using the 15 -yr average price for steers for the appropriate month and weight (Feuz et al., 2001).

${ }^{\mathrm{b}}$ Cow cost $=$ adjusted cow cost $($ Table 4$) \times 100$ cows.

'Total steer cost from weaning through slaughter with steer priced into the postweaning phase on an economic basis, excluding initial steer cost (Table 5$) \times(100 \times 0.865 \times 0.5)$.

${ }^{\mathrm{d} S t e e r}$ revenue derived from live weight sale (Table 5$) \times(100 \times 0.865 \times 0.5)$.

eWeaned heifer revenue using heifer weaning weight $(224 \mathrm{~kg})$ and the 15 -yr average price for heifers for the month weaned $(\$ 83.75 / 45 \mathrm{~kg}$, Feuz, 2001) $\times(100 \times 0.865 \times 0.5)$.

${ }^{\mathrm{f}}$ Steer revenue derived from grid-based sale $($ Table 5$) \times(100 \times 0.865 \times 0.5)$.

tems could decrease variation in final BW and final fat thickness, which, in turn, would lead to the production of additional carcass weight while avoiding carcass discounts.

Postweaning Financial Analysis. Table 6 shows the results of the postweaning analysis when steers are priced into the feedlot on a financial basis. Slaughter breakeven was lower $(P=0.03)$ for the TRT steers than for the CON steers. This difference was due to reduced initial steer cost and greater final weight for TRT steers.
Profit potential was greater $(P=0.07)$ for TRT steers compared with CON steers when finished steers were marketed using a live sale price. When grid pricing was used, net profit/loss was not different. Clearly, net revenue is affected when steers were priced into the system at their preweaning production cost (financial costs). Greater costs of production to weaning, as illustrated when pricing the steers into the postweaning phase using the financial basis, placed CON steers at a disadvantage compared with TRT steers, and subse-

Table 8. Net revenue or loss generated for control (CON) and treatment (TRT) systems when steers are priced into the postweaning phase of production on a financial (cost of production) basis, excluding management, labor, and overhead ${ }^{\mathrm{a}}$

\begin{tabular}{|c|c|c|c|c|}
\hline Item & $\mathrm{CON}$ & TRT & $P$-value & $\mathrm{SE}$ \\
\hline Cow cost, $\$^{\mathrm{b}}$ & $39,367.67$ & $36,454.00$ & - & - \\
\hline Steer cost (financial), $\$^{c}$ & $16,552.99$ & $20,484.34$ & - & - \\
\hline Total system cost, $\$$ & $55,920.66$ & $56,938.34$ & - & - \\
\hline Steer revenue (live basis), $\$^{\mathrm{d}}$ & $32,145.65$ & $38,365.89$ & - & - \\
\hline Heifer revenue, $\$^{\mathrm{e}}$ & $17,790.39$ & $17,790.39$ & - & - \\
\hline System revenue (live basis), $\$$ & $49,936.04$ & $56,156.28$ & - & - \\
\hline Net revenue/cow exposed (live basis), $\$$ & $(59.32)$ & $(8.35)$ & 0.06 & 9.75 \\
\hline Steer revenue (grid basis), $\$^{\mathrm{f}}$ & $33,142.25$ & $38,061.16$ & - & - \\
\hline Heifer revenue, $\$^{\mathrm{e}}$ & $17,790.39$ & $17,790.39$ & - & - \\
\hline System revenue (grid basis), $\$$ & $50,932.64$ & $55,851.55$ & - & - \\
\hline Net revenue/cow exposed (grid basis), $\$$ & (49.88) & (10.87) & 0.19 & 14.61 \\
\hline
\end{tabular}

${ }^{\mathrm{a}}$ Financial steer cost $=$ cost to produce a steer

${ }^{\mathrm{b}}$ Cow cost $=$ adjusted cow cost $($ Table 4$) \times 100$ cows.

${ }^{\mathrm{c}}$ Total steer cost from weaning through slaughter with steer priced into the postweaning phase on a financial basis, excluding initial steer cost (Table 6$) \times(100 \times 0.865 \times 0.05)$.

${ }^{\mathrm{d}}$ Steer revenue derived from live weight sale (Table 6) $\times(100 \times 0.865 \times 0.05)$.

${ }^{\text {e}}$ Weaned heifer revenue using heifer weaning weight $(224 \mathrm{~kg})$ and the 15 -yr average price for heifers for the month weaned $(\$ 83.75 / 45 \mathrm{~kg}$, Feuz, 2001$) \times(100 \times 0.865 \times 0.05)$.

${ }^{\mathrm{f}}$ Steer revenue derived from grid-based sale (Table 6$) \times(100 \times 0.865 \times 0.05)$. 
quently raised breakevens and resulted in greater losses than when they were priced into the finishing period on an economic basis. Klopfenstein (2001) noted that price differential paid for calves in a calf-finishing program compared with calves that are grown in a yearling program can affect breakeven and profitability.

Treatment Steer Economic and Financial Analysis by Period. In the TRT system, when steer calves were priced into the postweaning phase on an economic (Table 5) and financial (Table 6) basis, breakevens and net profit/loss were calculated after the winter and summer periods. After the winter period, TRT steers generated a breakeven of $\$ 0.83 / 0.45 \mathrm{~kg}$ and a loss of $\$ 30.18 /$ steer when steers were priced in on an economic basis. However, the breakeven after the summer period was $\$ 0.67$ and net profit was $\$ 50.07 /$ steer. When steers were priced into the winter period on a financial basis, breakeven was slightly lower, and steers had greater profit potential.

Profit potential was greater after the summer period than after both the winter and finishing periods when steers were priced into the postweaning phase on an economic and a financial basis. These data suggest that when calves are subjected to a slow rate of gain during the winter phase, they need to be retained through at least the spring/summer phase to increase their profit potential regardless of how the steers are priced into the system.

Systems. Table 7 reports the analysis of the CON and TRT groups when steers were priced into the system on an economic basis. Net profit/loss was improved $(P=$ 0.08 ) for the TRT system when compared with the CON system. This difference (\$42.28) is partly a function of the decreased cow costs in the TRT system. Even more influential was the cost and revenue spread between the CON and TRT steers postweaning. Treatment steers acquired over $\$ 114 /$ steer more costs than CON steers, but generated nearly $\$ 145 /$ steer more in finished steer revenue when sold on a live basis. As discussed previously, heavier slaughter weights resulted in improved net revenue when steers were sold on a live basis. In terms of total system evaluation, the TRT system marketed more weight per cow unit, and therefore had decreased losses compared with the CON system. In this study, treatment differences observed when steers were sold on a live basis disappeared when steers were sold on a grid basis because fewer steers in the TRT system graded USDA Choice compared with CON steers.

When steers were priced into the system on a financial basis, there were differences $(P=0.06)$ when steers were sold on a live basis (Table 8 ). These differences were again due to lower adjusted cow cost and greater profit potential realized in the sale of finished steers on a live basis for the TRT treatment group. The TRT system generated more weight to sell at the end of the feedlot period; however, again when steers were sold using the grid, because fewer TRT steers graded USDA Low Choice or better, profit potential was similar between treatment groups. As in the economic analysis, the issue of amount of weight marketed also affected profit potential.

\section{Summary}

The results of the current study indicate that differences in cow BW and condition after cornstalk grazing did not affect calving or weaning rates. Growing steers for a longer period of time on forage before a short finishing period resulted in higher ADG, decreased feed efficiency, and leaner, heavier carcasses. Steers managed in the CON system spent more days in the feedlot, were more efficient in converting gain to feed, and had higher marbling scores.

Economic analysis resulted in improved weaning breakeven and cost per weaned calf for the TRT system compared with the CON system. Postweaning economic analysis indicated lower breakeven for TRT steers, and TRT steers tended to be more profitable when sold on a live basis. Financial analysis indicated lower breakeven and improved profit potential for the TRT system when steers were sold on a live basis. Profit potential between systems did not differ when steers were sold on a grid basis regardless of how steers were priced into the postweaning phase. Total systems evaluation resulted in improved profit potential for the TRT system when steers were sold on a live basis, regardless of how they were priced into the system.

\section{Literature Cited}

Adams, D. C., R. T. Clark, T. J. Klopfenstein, and J. D. Volesky. 1996. Matching the cow with forage resources. Rangelands 18(2):57-62.

Adams, D. C., M. K. Nielsen, W. H. Schacht, and R. T. Clark. 2000. Designing and conducting experiments for range beef cows. Proc. Am. Soc. Anim. Sci., 1999. Available: www.asas.org.jas.symposia/proceedings/0947.pdf. Accessed Dec. 28, 2001.

Erickson, G. E. 1997. Evaluation of protein and phosphorus requirements of feedlot cattle: Effects on performance and waste management. M.S. Thesis, Univ. of Nebraska.

Feuz, D. M. 2001. Economics of young female management. Pages 171-175 in Proc. Range Beef Cow Symp. XVII, Casper, WY.

Feuz, D. M., P. A. Burgener, and T. Holman. 2001. Historical Cattle and Beef Prices, Seasonal Patterns, and Futures Basis for Nebraska, 1960-2000. Univ. of Nebraska Coop. Ext. Publ. PHREC01-21.

Freetly, H. C., C. L. Ferrell, and T. G. Jenkins. 2000. Timing of realimentation of mature cows that were feed-restricted during pregnancy influences calf birth weights and growth rates. J. Anim. Sci. 78:2790-2796.

Gill, D. R., M. C. King, D. S. Peel, H. G. Dolezal, J. J. Martin, and C. A. Strasia. 1993. Starting age: Effects on economics and feedlot carcass characteristics of steers. Oklahoma Agric. Exp. Stn. Rep. MP-933:197.

Guiroy, P. J., D. G. Fox, L. O. Tedeshi, M. J. Baker, and M. D. Cravey. 2001. Predicting individual feed requirements of cattle fed in groups. J. Anim. Sci. 79:1983-1995.

Hancock, D. L., J. E. Williams, H. B. Hedrick, E. E. Beaver, D. K. Larrick, M. R. Ellersieck, G. B. Garner, R. E. Morrow, J. A. Paterson, and J. R. Gerrish. 1987. Performance, body composition, and carcass characteristics of finishing steers as influenced by previous forage systems. J. Anim. Sci. 65:1381-1391. 
Hickok, D. T., R. R. Schalles, M. E. Dikeman, and D. E. Frake. 1992. Comparison of feeding calves vs. yearlings. Kansas Agric. Exp. Stn. Rep. of Prog. SRP651:64-65.

Johnson, B. B., P. Brummels, and L. Kuenning. 2001. Nebraska farm real estate market developments 2000-2001. Univ. of Nebraska Coop. Ext. Publ. EC01-809-S.

Jordon, D. J. 2000. Performance and slaughter breakeven analysis of calf and yearling systems and compensatory growth. Ph.D. Diss., Univ. of Nebraska, Lincoln.

Klopfenstein, T., R. Cooper, D. J. Jordon, D. Shain, T. Milton, C. Calkins, and C. Rossi. 2000. Effects of backgrounding and growing programs on beef carcass quality and yield. Pages 1-9 in Proc. Am. Soc. Anim. Sci. 1999. Am. Soc. Anim. Sci., Savoy, IL.

Klopfenstein, T. J., D. J. Jordon, and G. E. Erickson. 2001. A systems approach to production from weaning to harvest. Pages 100-110 in Proc. Range Beef Cow Symp. XVII, Casper, WY.

Lunt, D. K., and L. E. Orme. 1987. Feedlot performance and carcass evaluation of heifers fed finishing diets as weanling calves or as yearlings. Meat Sci. 20:159-164.

MacDonald, J. C. 2002. Sorting strategies in an extensive forage utilization beef production system. M.S. Thesis. Univ. of Nebraska, Lincoln.

Mark, D. R. 2001. Weather effects on feedlot cattle performance and profitability. Ph.D. Diss., Kansas State Univ., Manhattan.

Morrison, D. G., J. C. Spitzer, and J. L. Perkins. 1999. Influence of prepartum body condition score change on reproduction in multiparous beef cows calving in moderate body condition. J. Anim. Sci. 77:1048-1054.

Rasby, R., M. Frazier, G. Deutscher, I. Rush, T. Mader, J. Gosey, and D. Hudson. 1990. Integrated resource management. Pages
23-30 in Proc. Low Input Sustain. Agric. Beef and Forage Conf., Omaha, NE.

Richards, M. W., J. C. Spitzer, and M. B. Warner. 1986. Effect of varying levels of postpartum nutrition and body condition at calving on subsequent reproductive performance in beef cattle. J. Anim. Sci. 62:300-306.

Selk, G. E., R. P. Wettemann, K. S. Lusby, J. W. Oltjen, S. L. Mobley, R. J. Rasby, and J. C. Garmendia. 1988. Relationships among weight change, body condition and reproductive performance of range beef cows. J. Anim. Sci. 66:3153-3159.

Selley, R. A., T. Barrett, L. L. Bitney, R. T. Clark, D. M. Feuz, and H. D. Jose. 2001a. Nebraska livestock budgets. Univ. of Nebraska Coop. Ext. Publ. EC01-818-S.

Selley, R. A., D. M. Feuz, and T. Barrett. 2001b. Crop and livestock prices for Nebraska producers. Univ. of Nebraska Coop. Ext. Publ. EC01-883-C.

Shain, D., T. Klopfenstein, D. J. Jordan, and R. Stock. 1998. Summer and fall forage grazing combinations: Five-year summary. Nebraska Beef Cattle Report. MP69:66-69. University of Nebraska, Lincoln.

Sindt, M., R. Stock, and T. Klopfenstein. 1991. Calf versus yearling finishing. Nebraska Beef Cattle Report MP56:42-43. University of Nebraska, Lincoln.

Smith, R. A. 1998. Impact of disease on feedlot performance: A review. J. Anim. Sci. 76:272-274.

Stock, R., T. Klopfenstein, and M. Sindt. 1990. Low input growingfinishing systems. Pages 45-63 in Proc. Low Input Sust. Agric. Beef and Forage Conf., Omaha, NE.

Van Koevering, M. T., D. R. Gill, F. N. Owens, H. G. Dolezal, and C. A. Strasia. 1995. Effect of time on feed on performance of feedlot steers, carcass characteristics, and tenderness and composition of longissimus muscle. J. Anim. Sci. 73:21-28. 